\title{
MARINE ALGAE OF TUKRA AND TOLMETA COASTS, LIBYA
}

\author{
Alaa. A. Said ${ }^{*}$ and Massoud M. Godeh \\ Botany Department, Faculty of Science, Garyounis University, Benghazi, \\ Libya
}

\begin{abstract}
The present investigation was mainly intended to make a recent data base of marine algal flora of Libyan coast which extend about $1900 \mathrm{Km}$. Seventy five marine algal species (53 genera) were collected and identified from two sampling stations at Tukra and Tolmeta coasts at the eastern Libyan coast. Eleven species (14.17\%) belong to Chlorophyta, Seventeen species (22.67\%) belonging to Phaeophyta (with special reference to genera Cystosiera) and forty seven species (62.67\%) belonging to Rhodophyta which showed clear dominancy. The two coasts shared $17.33 \%$ of species (13). Tukra coast was richer of algal species (74.67\%) all representing algal groups. It also characterized by 43 dominant species. Meanwhile, Tolmeta coast was relatively poor, only 32 species were found. Regarding to Chlorophyta, the similarity index between the two coasts was relatively high (70.59\%). On the other hand, it was relatively low (30\%, 15.69 and $27.21 \%$ ) between Phaeophyta, Rhodophyta and total algae, respectively. Many of the collected algae are good ecological quality indicators having economic importance and need further investigations.
\end{abstract}

Key words: Chlorophyta, Marine macroalgae, Phaeophyta, Rhodophyta, R/P ratio, Species richness index and Similarity index.

\section{Introduction}

The first record of Libyan marine algae was recorded by the Italian scientist Ardissone (1893) then Nizamuddin et al. (1979) listed marine algae of Libya. Nizamuddin and Godeh (1989, 1990 a, b \& c and 1993) and Nizamuddin and ElMenifi (1993) recorded many new species of marine algae at eastern Libyan coast. The last list of Libyan marine algae (168 species) was made by Godeh et al. (1992).

Deep sub tidal rocky habitats of Mediterranean Sea are characterized by assemblages dominated by calcareous organisms which have important role in carbonate cycle (Ballesteros, 2006). In Mediterranean Sea, invasions of exotic macroalgae have caused serious ecological problems in costal areas (Boudouresque and Verlaque, 2002). Most of green, brown and red seaweeds or macroalgae have economic potential (Critchley et al., 1998) and used as ecological quality indicators (Pinedo, et al., 2007) so, more than 500 species safely now used as direct and indirect human and fish food (Dawes, 1998) because they are a rich of nutritive materials, structurally novel and biologically 
active metabolites and used in new pharmaceutical industries (Lima-Filho et al.: 2002: Ely et al., 2004 and Tüney et al., 2006) and recently showed antimicrobial activities (Hafez et al., 2005; El-Gahmy, 2007 and El-Fatemi, 2008). The economic success of these crops depends greatly upon detailed basic knowledge of the algae (Linda and Lee, 2000).

More recent researches still needed to collect, identify and evaluate the great importance of marine algae of the very rich Libyan coast which extend about $1900 \mathrm{Km}$. southern Mediterranean Sea at the eastern north part of Africa. The aim of this paper is to describe the algal species composition and its biodiversity in two different eastern Libyan coasts and to compare them to reference assemblages.

\section{Material and Methods}

\section{The Study area:}

The geographical location of the study area is illustrated in Figure 1. Tukra coast lies about $100 \mathrm{Km}$. northern east Benghazi while, Tolmeta coast lies, about $150 \mathrm{Km}$. northern east Benghazi at $32^{\circ} 41^{\prime} 45.68^{\prime \prime} \mathrm{N}$ and $20^{\circ} 57^{\prime} 38.99^{\prime \prime} \mathrm{E}$. Their open rocky shores had little sandy shores and some small rocky islands very closed to their beach. They are also had a very small fishing ports without any pollution and human beings activities.

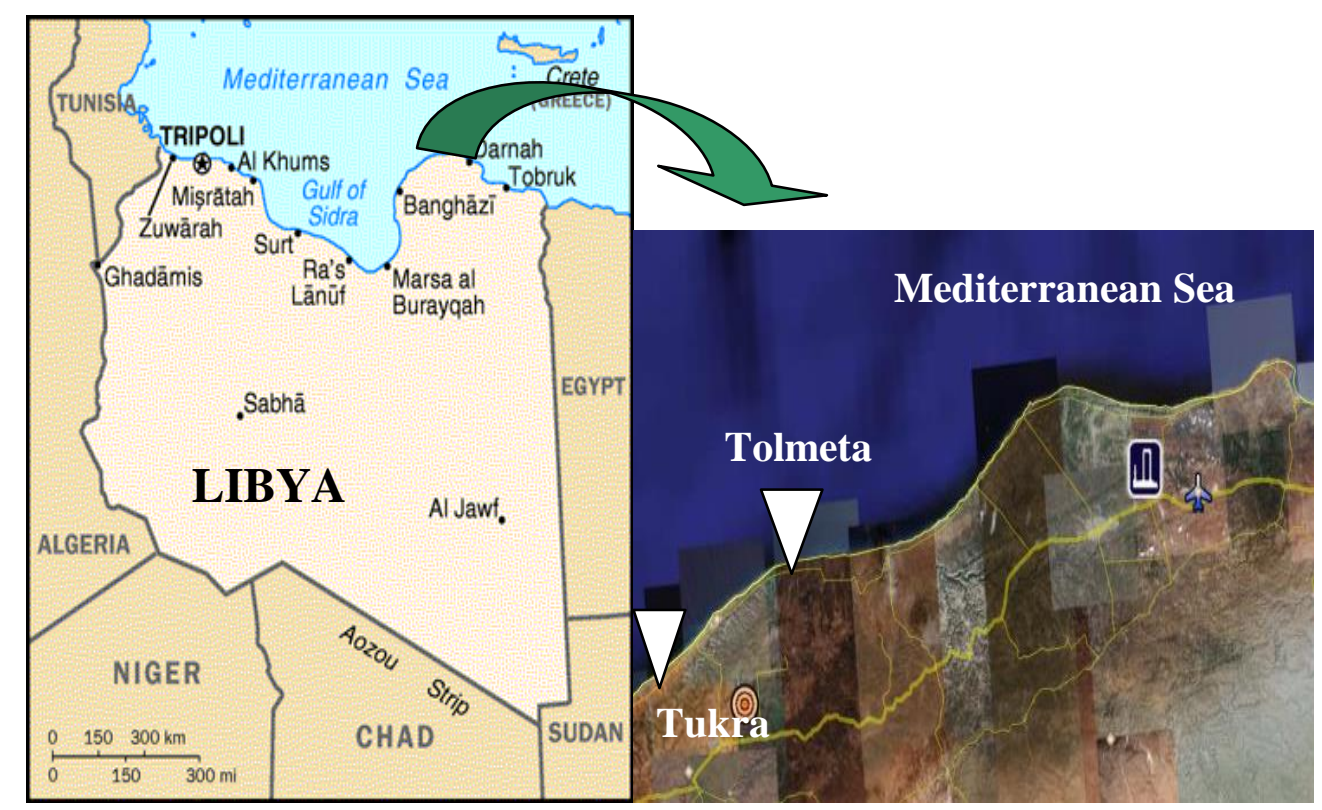

Figure 1. Maps of Libya and the study area. 


\section{Sampling and sample preparations:}

Specimens were harvested generally in the morning in ice tanks at nylon or polyethylene bags sprinkled with $4 \%$ formalin sea water solution for mounting on the herbarium sheets, glass bottles and some of them kept freshly at refrigerators for future use and subsequent taxonomic identification using Ardissone Italian list (1893), Pampanini (1931), Burrows (1991) and Aleem (1993). Epiphytes, impurities and salts were removed carefully and quickly at laboratory with tap and distilled waters. The herbarium sheets have been deposited in the Herbarium, Department of Botany, Garyounis University, Benghazi [CHUG nos. FM. 650; 651]. Longitudinal and transverse sections of the axis at the apexes, midfronds and the bases were hand made and stained in $1 \% \mathrm{KI}_{2}$ or Anilin blue solution.

\section{Species richness:}

Species richness index calculated according to Wilhm (1975) by direct count of different algal species (taxa) at every sampling site where, the decrease in number of species and increase in number of individuals is a characteristic feature of polluted water.

\section{Similarity index:}

The similarity was calculated as statistical parameter by the equation of Sorenson (1948) to assess the degree of similarity between algal species composition of pairs of stations under investigation which, depends upon the presence or absence of different taxa:

$$
\mathrm{IS}_{\mathrm{s}}=(\mathbf{2 C} \times \mathbf{1 0 0}) / \mathrm{A}+\mathrm{B}
$$

Where: IS $_{\mathrm{s}}=$ similarity quotient .

$\mathrm{C}=$ number of species common to both site.

$A=$ number of species in the first site.

$\mathrm{B}=$ number of species in the second site.

\section{Results and Discussion}

A total of 75 macroalgal species and 54 genera were found at the study area. The results were more or less qualitatively and quantitatively similar to those of Diaz-Valdes, et al. (2007) who identified 65 Littoral macroalgae using them to assess the environmental quality of Valencian rocky coasts (SE Spain). Diapoulis and Tsiamis (2007) also found 88 marine benthic macroalgal taxa at the upper infralittoral zone of South Aegean Sea (Greece). Contrarily, Rhodes Island which can be considered relatively richer had a total of 155 macroalgal taxa (Tsiamis et al., 2007). 
Chlorophyta were represented by Just eleven species (14.67\%), nine genera $(16.67 \%)$ of the total recorded algae (Table 1), The reduction of green species may be due to the presence of Caulerpales which considered strong competitors (David et al., 2004 and Piazzi et al., 2005) and its production of toxic substances, which inhibit their grazing (Piazzi et al., 2005).

Table (1). Distribution of green marine macroalgae at Tukra and Tolmeta coasts.

\begin{tabular}{||l|c|c||}
\hline \hline Chlorophyta & Tukra & Tolmeta \\
\hline Acetabularia Lamouroux 1817 & & \\
\hline Acetabularia acetabulum (lamx.) Silva & + & + \\
\hline Anadyomene Lamouroux 1812 & & \\
\hline Anadyomene stellata (Wulf.) C. Agardh & + & + \\
\hline Caulerpa Lamouroux 1809 & & \\
\hline Caulerpa prolifera (Forsskål) Lamouroux & + & + \\
\hline Cladophora Kützing 1843 & & \\
\hline Cladophora prolifera (Roth) Kützing & + & - \\
\hline Cladophora nigrescens Zan. éx Frauenfeld & + & - \\
\hline Codium Stackhouse 1797 & & \\
\hline Codium decorticatum (Woodw.) Howe & + & - \\
\hline Codium difforme (Kützing) Kützing & + & - \\
\hline Dasycladus C. Agardh 1828 & & \\
\hline Dasycladus vermicularis (Scopoli) Krasser & + & + \\
\hline Flabellia Reichenbach (Udtea Lamouroux) & & \\
\hline Flabellia petiolata (Turva) Nizamuddin & + & + \\
\hline Halimeda Lamouroux 1816 & & \\
\hline Halimeda tuna (Ellis ét Solander) Lamouroux & + & + \\
\hline Ulva Linnaeus 1753 & $\mathbf{9}$ & $\mathbf{+ 1}$ \\
\hline Ulva lactuca Linnaeus & & $\mathbf{6}$ \\
\hline \multicolumn{1}{|c||}{ Number of genus } & \\
\hline
\end{tabular}

Seventeen species (22.67\%), eight genera (14.81\%) of them were belonging to Phaeophyta (Table 2). Genus Cystosiera are the most abundant ones at both coasts. Cystosiera species are usually the dominant element of the benthic vegetation on unpolluted hard substratum (Peres and Picard, 1964) and could used as an additional important argument for securing a more wise and sustainable use of the coastal ecosystem that they indeed play a critical role in the conservation of species and habitat diversity (Turk et al., 2007).

Rhodophyta showed clear dominancy (Table 3) by forty seven species (68.52\%), thirty seven genera (67.92\%). The result was slightly similar to South Aegean Sea (Greece) which dominated by 60 red algal taxa (Diapoulis and Tsiamis, 2007).

Egyptian J. of Phycol. Vol. 9, $2008 \quad$ - 170 - 
Table (2). Distribution of brown marine macroalgae at Tukra and Tolmeta coasts.

\begin{tabular}{|c|c|c|}
\hline Phaeophyta & Tukra & Tolmeta \\
\hline \multicolumn{3}{|l|}{ Cystosiera C. Agardh 1820} \\
\hline Cystosiera barbata (Good ét Wood) J. Agardh & + & + \\
\hline Cystosiera cinitophylla Ercegovic & - & + \\
\hline Cystosiera compressa Gerloffi ét Nizamuddin & + & + \\
\hline Cystosiera elegans Sauvageau ét Feldmann & - & + \\
\hline Cystosiera discors (Linn.) C. Agardh emend Sauvageau & - & + \\
\hline Cystosiera gerloffi Nizamuddin & - & + \\
\hline Cystosiera susanensis Nizamuddin & + & - \\
\hline Cystosiera stricta (Montagne) Sauvageau & - & + \\
\hline \multicolumn{3}{|l|}{ Dictyopteris Lamouroux 1809} \\
\hline Dictyopteris membranacea (Skackhouse) Batters & - & + \\
\hline Dictyopteris tripolitana Nizamuddin & + & + \\
\hline \multicolumn{3}{|l|}{ Dictyota Lamouroux 1809} \\
\hline Dictyota dichotoma (Hudson) lamouroux & - & + \\
\hline \multicolumn{3}{|l|}{ Ectocarpus Lyngbye emend. Hamel } \\
\hline Ectocarpus confervoides (Roth) Kiellman & + & - \\
\hline \multicolumn{3}{|l|}{ Padina Adanson 1763} \\
\hline Padina pavonia (Linnaeus) Lamouroux & - & + \\
\hline \multicolumn{3}{|l|}{ Sargassum C. Agardh 1820} \\
\hline Sargassum acinarium C. Agardh & + & - \\
\hline Sargassum hornscuchii C. Agardh & - & + \\
\hline \multicolumn{3}{|l|}{ Scytosiphon C. Agardh 1820} \\
\hline Scytosiphon lomentaria (Lyngbye) Lamouroux & - & + \\
\hline \multicolumn{3}{|l|}{ Taonia J. Agardh 1848} \\
\hline Taonia atamaria (Woodward) J. Agardh var. atamaria & + & - \\
\hline Number of genus & 5 & 6 \\
\hline Number of species & 7 & 13 \\
\hline
\end{tabular}

Tukra coast is richer of algal species than Tolmeta coast (Table 4 and Figure 2). Tukra characterized by 43 species $(57.33 \%)$ and 30 genera $(55.56 \%)$. Chlorophyta represented by 5 species $(11.63 \%)$ and 3 genera $(10.00 \%)$, Phaeophyta represented by 4 species $(9.30 \%)$ and 2 genera $(6.67 \%)$ and Rhodophyta represented by 34 species $(79.07 \%)$ and 25 genera $(67.76 \%)$. At relatively similar area and conditions, Godeh et al. (2008) reported that, Tobruk coast characterized by thirty six species of different marine algae.

Meanwhile, Tolmeta characterized alone by only 19 species $(25.33 \%)$ and 11 genera $(20.37 \%)$. There are no any characterized species of Chlorophyta, 
Table (3). Distribution of red marine macroalgae at Tukra and Tolmeta coasts.

\begin{tabular}{|c|c|c|}
\hline Rhodophyta & Tukra & Tolmeta \\
\hline \multicolumn{3}{|l|}{ Acrosorium Zanardini 1869} \\
\hline Acrosorium uncinatum (J. Agardh) kylin & - & + \\
\hline \multicolumn{3}{|l|}{ Alsidium C. Agardh 1827} \\
\hline Alsidium coraillinum (Tur.) Kützing & + & - \\
\hline Alsidium helmithochooton (Tur.) Kützing & + & - \\
\hline \multicolumn{3}{|l|}{ Amphiroa Lamouroux } \\
\hline Amphiroa rigida Lamouroux & - & + \\
\hline \multicolumn{3}{|l|}{ Borgeseniella Kylin } \\
\hline Borgeseniella purfruticulos (Wulf.) Kylin & + & - \\
\hline \multicolumn{3}{|l|}{ Botryocladia Kylin 1931} \\
\hline Botryocladia botryoides (Wulf.) Feldmann & - & + \\
\hline \multicolumn{3}{|l|}{ Ceramium Roth 1797} \\
\hline Ceramium diaphanum var. elegans (Roth) Feldmann ét Mazoyer & + & - \\
\hline \multicolumn{3}{|l|}{ Chondria C. Agardh 1817} \\
\hline Chondria coerulescens (Stackhouse ét Wood word) Falkenberg & + & - \\
\hline Chondria dasyphylla (Stackhouse ét Wood word) J. Agardh & + & - \\
\hline \multicolumn{3}{|l|}{ Chondriopsis J. Agardh 1863} \\
\hline Chondriopsis mediterranea (Kütz.) J. Agardh & + & + \\
\hline \multicolumn{3}{|l|}{ Chrysmenia J. Agardh 1842} \\
\hline Chrysmenia ventricosa (Lamour.) J. Agardh & - & + \\
\hline \multicolumn{3}{|l|}{ Corallina Linnaeus 1758} \\
\hline Corallina granifera Ellis ét Solander & + & - \\
\hline Corallina officinalis Linnaeus & + & - \\
\hline \multicolumn{3}{|l|}{ Dasya C.Agardh 1822} \\
\hline Dasya lallemandii Moneghne & + & - \\
\hline Dasya villosa Harvy & + & - \\
\hline Dasya rigidula (Kütz.) Ardissone & + & - \\
\hline \multicolumn{3}{|l|}{ Dermatolithon Forslie } \\
\hline Dermatolithon pustulatum (Lamouroux) Foslie & - & + \\
\hline \multicolumn{3}{|l|}{ Digenia C. Agardh 1822} \\
\hline Digenia simplex (Wulf.) C. Agardh & + & - \\
\hline \multicolumn{3}{|l|}{ Fosliella Howe } \\
\hline Fosliella farinose (Lamour) Howe & + & - \\
\hline Fosliella lejolisii (Ros.) Howe & + & - \\
\hline \multicolumn{3}{|l|}{ Gracilaria Greville 1830 (Hud.) } \\
\hline Gracilaria verrucosa (Hud.) Papenfuss & + & - \\
\hline \multicolumn{3}{|l|}{ Griffithsia C. Agardh 1817} \\
\hline Griffithsia barbata (Huds.) C. Agardh & + & - \\
\hline \multicolumn{3}{|l|}{ Halopitys Kützing Itys 1849} \\
\hline Halopitys incurvus (Hud.) Batters Itys & + & - \\
\hline \multicolumn{3}{|l|}{ Halurus Kützing 1843} \\
\hline Halurus equisetifolius (Lightf.) Kützing & + & - \\
\hline
\end{tabular}




\begin{tabular}{|c|c|c|}
\hline \multicolumn{3}{|l|}{ "Herposiphonia Nageli 1846} \\
\hline Herposiphonia secunda (C. Agardh) Ambronn & + & - \\
\hline \multicolumn{3}{|l|}{ Hypnea Lamouroux 1813} \\
\hline Hypnea musciformis (Wulf.) Lamouroux & + & + \\
\hline \multicolumn{3}{|l|}{ Hypoglossum Küitzing 1843} \\
\hline Hypoglossum crispum Kützing & + & - \\
\hline \multicolumn{3}{|l|}{ Jania Lamouroux 1812} \\
\hline Jania adhaerens Lamouroux & - & + \\
\hline Jania rubens (Linnaeus) Lamouroux & - & + \\
\hline \multicolumn{3}{|l|}{ Laurencia Lamouroux 1813} \\
\hline Laurencia liophora Kützing & + & - \\
\hline Laurencia obtusa (Hudson) Lamouroux & + & - \\
\hline Laurencia paniculata (C. Agardh) Kützing & + & - \\
\hline Laurencia papillosa (Forsskål) C. Agardh & + & + \\
\hline \multicolumn{3}{|l|}{ Liagora Lamouroux 1812} \\
\hline Liagora viscida (Forsskål) C. Agardh & + & - \\
\hline \multicolumn{3}{|l|}{ Lophosiphonia Falkenberg 1897} \\
\hline Lophosiphonia obscura (C. Agardh) & + & - \\
\hline \multicolumn{3}{|l|}{ Mesophyllum Lemoine } \\
\hline Mesophyllum lichenoides (Ellis ét Solmander) Lemoine & - & + \\
\hline \multicolumn{3}{|l|}{ Neogoniolithon Setchell ét Mason } \\
\hline Neogoniolithon mamiilusum (Hauck) Hewe & + & - \\
\hline \multicolumn{3}{|l|}{ Peyssonnelia Decaisne 1842} \\
\hline Peyssonnelia elegella Harvey & - & + \\
\hline \multicolumn{3}{|l|}{ Phyllophora Greville } \\
\hline Phyllophora nervosa (De Cand.) Greville & + & - \\
\hline \multicolumn{3}{|l|}{ Plocamium Lamouroux 1913} \\
\hline Plocamium cartilagineum (Lann.) Dixon & + & - \\
\hline \multicolumn{3}{|l|}{ Polysiphonia greville 1830} \\
\hline Polysiphonia castilliana Denotaris ét Dufour greville & + & - \\
\hline \multicolumn{3}{|l|}{ Ricardia Derbes et Solier 1856} \\
\hline Ricardia montagnei Derbes ét Solier & + & - \\
\hline \multicolumn{3}{|l|}{ Rhodochorton Nageli 1862} \\
\hline Rhodochorton floridulum (Dillwyn) Nageli & + & - \\
\hline \multicolumn{3}{|l|}{ Rytiphlaea C. Agardh 1824} \\
\hline Rytiphlaea tinctoria (Clemente) C. Agardh & + & + \\
\hline \multicolumn{3}{|l|}{ Sphaerococcus Stackhouse } \\
\hline Sphaerococcus coronopifolius Stackhouse ét Wood Word & + & - \\
\hline \multicolumn{3}{|l|}{ Viladia Lamouroux 1822} \\
\hline Viladia volubilis (Linn.) J. Agardh & + & - \\
\hline \multicolumn{3}{|l|}{ Wrangelia C. Agardh } \\
\hline Wrangelia penicillata (C. Agardh) C. Agardh & + & - \\
\hline Number of genus & 29 & 12 \\
\hline Number of species & 38 & 13 \\
\hline
\end{tabular}


Phaeophyta represented by 10 species $(52.63 \%)$ and 3 genera $(27.27 \%)$ and Rhodophyta represented by 9 species (47.37\%) and 8 genera (72.73\%).

Table 4. Distribution of algal genera and species at Tukra and Tolmeta coasts.

\begin{tabular}{|c|c|c|c|c|c|c|c|c|c|}
\hline \multicolumn{2}{|c|}{ Algae Coasts } & \multicolumn{2}{|c|}{$\begin{array}{c}\text { Recorded at } \\
\text { Tukra only }\end{array}$} & \multicolumn{2}{|c|}{$\begin{array}{c}\text { Recorded at } \\
\text { Tolmeta only }\end{array}$} & \multicolumn{2}{|c|}{$\begin{array}{c}\text { Shared at both } \\
\text { coasts }\end{array}$} & \multicolumn{2}{|c|}{ Total } \\
\hline \multirow{5}{*}{ 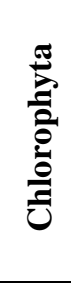 } & \multirow{3}{*}{ genus } & No. & $\%$ & No. & $\%$ & No. & $\%$ & No. & $\%$ \\
\hline & & 3 & 33.33 & 0.0 & 0.00 & 6 & 66.67 & \multirow{2}{*}{9} & \multirow{2}{*}{16.67} \\
\hline & & 10.0 & & 0.00 & & 46.15 & & & \\
\hline & \multirow{2}{*}{ species } & 5 & 45.45 & 0.0 & 0.00 & 6 & 54.54 & \multirow{2}{*}{11} & \multirow{2}{*}{14.67} \\
\hline & & 11.63 & & 0.00 & & 46.15 & & & \\
\hline \multirow{4}{*}{ 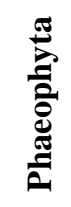 } & \multirow{2}{*}{ genus } & 2 & 25 & 3 & 37.5 & 3 & 37.5 & \multirow{2}{*}{8} & \multirow{2}{*}{14.81} \\
\hline & & 6.67 & & 27.27 & & 23.08 & & & \\
\hline & \multirow{2}{*}{ species } & 4 & 23.53 & 10 & 58.82 & 3 & 17.65 & \multirow{2}{*}{17} & \multirow{2}{*}{22.67} \\
\hline & & 9.30 & & 52.63 & & 23.08 & & & \\
\hline \multirow{4}{*}{ 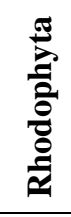 } & \multirow{2}{*}{ genus } & 25 & 67.76 & 8 & 21.62 & 4 & 10.81 & \multirow{2}{*}{37} & \multirow{2}{*}{67.92} \\
\hline & & 83.33 & & 72.73 & & 30.77 & & & \\
\hline & \multirow{2}{*}{ species } & 34 & 72.34 & 9 & 19.15 & 4 & 8.51 & \multirow{2}{*}{47} & \multirow{2}{*}{68.52} \\
\hline & & 79.07 & & 47.37 & & 30.77 & & & \\
\hline \multirow{2}{*}{$\stackrel{\bar{\sigma}}{\frac{\pi}{\theta}}$} & genus & 30 & 55.56 & 11 & 20.37 & 13 & 24.07 & \multicolumn{2}{|c|}{54} \\
\hline & species & 43 & 57.33 & 19 & 25.33 & 13 & 17.33 & \multicolumn{2}{|c|}{75} \\
\hline
\end{tabular}

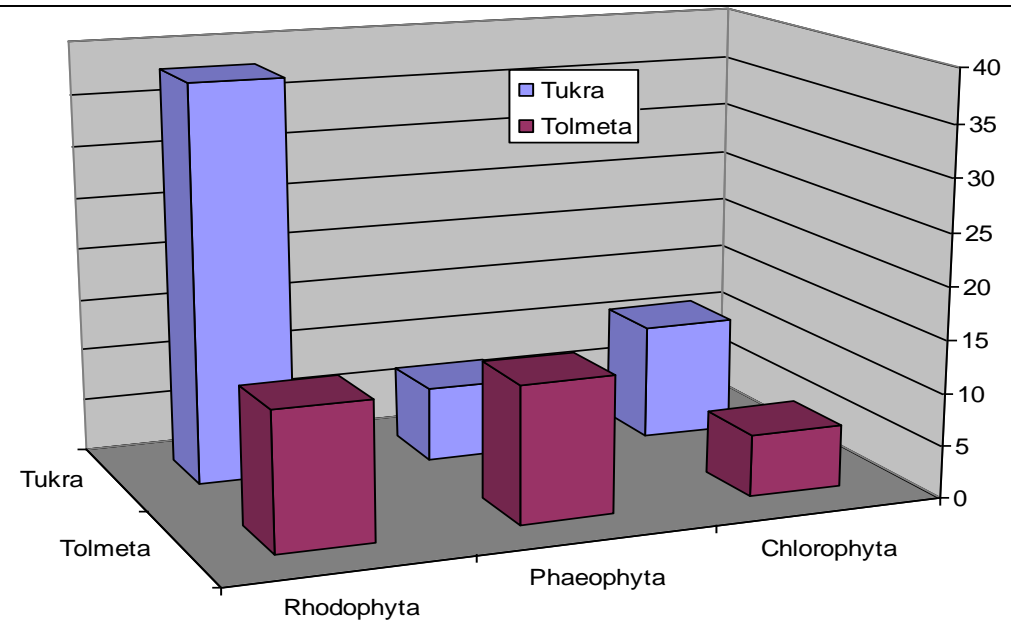

Figure 2. The presence of different marine algal groups Tukra and Tolmeta coasts 
According to the species richness indication of Wilhm (1975) one could conclude that, Tukra coast is more pure and sustained than Tolmeta coast. Said et al. (2005) used the species richness parameters carefully to evaluate the purity and pollution state of different four water bodies.

Both coasts shared together by 13 species (17.33\%) and 13 genera (24.07\%). Six species $(46.15 \%)$ and 6 genera $(46.15 \%)$ belonging to Chlorophyta, 3 species $(23.08 \%)$ and 3 genera $(23.08 \%)$ belonging to Phaeophyta and 4 species (30.77\%) and 4 genera (30.77\%) belonging to Rhodophyta (Table 4).

The R/P ratio of Tukra is very high (5.43) due to the clear dominancy of Rhodophyta. Meanwhile, it is equal at Tolmeta due to the balance of both Rhodophyta and Phaeophyta (13 species of each). Nearest to these of Rhodes Island, Greece (3.5), this suggests a warm-temperate aspect of macroalgal flora (Tsiamis, 2007). This value corresponding to other macroalgal studies of the Greek coasts (Lazarido, 1994; Tsirika, 2005). Nizamuddin (1985) evaluated that eastern Libyan coasts were generally poor in algal growth and continuously exposed to rough conditions and fluctuating cold to mild weather because they belong to Pleistocene deposits. According to the finding of Diaz-valdes et al. (2007) and Pinedo, et al. (2007) many of the identified marine algal taxa considered as indicators to the good and very good ecological quality waters like, Cystoseira, Corallina, Hypnea, Jania and Laurencia.

Regarding to the similarity index between the two coasts (Tables 5and6), using the equation of Sorenson (1948) depending upon the presence or absence of different taxa, is relatively high $(70.59 \%)$ only between Chlorophyta, while it is relatively low (30\%, 15.69\% and 27.21\%) between Phaeophyta, Rhodophyta and total algae, respectively. Godeh et al. (2008) evaluated that, the similarity index between the total algae of Tolmeta coast and some eastern Libyan coasts like Derna and Susa were $24 \%$ and $57.14 \%$, respectively.

Table 5. Similarity index between Tukra and Tolmeta coasts according to Chlorophyta (above diagonal) and Phaeophyta (below diagonal).

\begin{tabular}{|c|c|c|}
\hline Coasts & Tukra & Tolmeta \\
\hline Tukra & $100 \%$ & $\mathbf{7 0 . 5 9 \%}$ \\
\hline Tolmeta & $\mathbf{3 0 \%}$ & $100 \%$ \\
\hline
\end{tabular}


Table 6. Similarity index between Tukra and Tolmeta coasts according to Rhodophyta (above diagonal) and Total algae (below diagonal).

\begin{tabular}{|c|c|c|}
\hline Coasts & Tukra & Tolmeta \\
\hline Tukra & $100 \%$ & $\mathbf{1 5 . 6 9 \%}$ \\
\hline Tolmeta & $\mathbf{2 7 . 2 1 \%}$ & $100 \%$ \\
\hline
\end{tabular}

\section{Acknowledgements}

Deep thanks to the research and consultancies center of Garyounis University for their supporting and providing all research facilities.

\section{References}

Aleem, A. A. (1993). The marine algae of the Alexandria, Egypt.

Ardissone, F. (1893). Note alla Phycologia mediterranea. Rend. R. Inst. Lombardo Sci. Lett. Ser., 26: 674-690.

Ballesteros, E. (2006). Mediterranean coralligenous assemblages: a synthesis of present knowledge. Ocean. Mar. Biol. Ann. Rev., 44:123-195.

Boudouresque, C. F. and Verlaque, M. (2002). Biological pollution in the Mediterranean Sea: invasive versus introduced macrophytes. Mar. Poll., 44: 32-38.

Burrows, E. M. (1991). Seaweeds of the British Isles. Volume 2. Chlorophyta. London: British Museum (Natural History), UK.

Critchley, A. T.; Gillespie, R. D. and Rotman, K. W. G. (1998). Seaweed resources of South Africa. Pp. 413-425. In: Critchley A. T. Ohno M (eds), Seaweed resources of the world. Japan International Cooperation Agency, Japan.

David, B.; Luigi, P. and Francesco, C. (2004). A Comparison Among Assemblages in Areas Invaded by Caulerpa taxifolia and C. racemosa on a Subtidal Mediterranean Rocky Bottom. Mar. Ecol., 25 (1): 1-13.

Dawes, C. J. (1998). Marine Botany. John Wiley and Sons, New York.

Diapoulis, A. and Tsiamis, K. (2007). Marine flora and vegetation of South Agean Sea (Greece). Proceeding of the $3^{\text {rd }}$ Mediterranean symposium on marine vegetation. Marseilles. 27-29 March 2007 - 263-264. France. 
Diaz-Valdes, M.; Abellan, E.; Izquierdo, A. and Ramos-Espla, A. (2007). Evaluation of the macroalgae communities in the Valencian rocky coasts (SE Spain) for the European Water Framework Directive (WFD). Proceeding of the $3^{\text {rd }}$ Mediterranean symposium on marine vegetation. 2729 March 2007 - Marseilles. 265-266. France.

El-Fatemi, A. S. (2008). Study of the effective of some brown algal species extractions (order: Dictyotales) against pathogenic fungi. M. Sc. Thesis, Botany Department, Faculty of Science, Garyounis University, Libya. (in Arabic).

El-Gahmy, H. A. (2007). Study of the effective of some green algal species extractions (order: Ulvales) against pathogenic bacteria and fungi. M. Sc. Thesis, Botany Department, Faculty of Science, Garyounis University, Libya. (in Arabic).

Ely, R.; Supriya, T. and Naik, C. G. (2004). Antimicrobial activity of marine organisms collected off the coast of south East India. J. Exp. Biol. and Ecol., 309: 121 - 127.

Godeh, M.; Nizamuddin, M. and El-Menifi, F. (1992). Marine algae from eastern coast of Libya (Cyrenaica). Pak. J. Bot., 24(1):11-21.

Godeh M. M.; El-Menifi, F. O. and Said, A. A. (2008). Marine algae of Tobruk and Ain Ghazala coasts, Libya. Journal of Science and its Applications. Faculty of Science, Garyounis University, Benghazi, Libya. (in press).

Hafez, S. S.; El-Manawy, I. M.; El-Ayouty, Y. M.; El-Adel, H. M. and Eraqi, I. S. (2005). Phytochemical investigation and antimicrobial activity of Ulva lactuca (L.). Pull. Faculty of Science, Zagazig University, 27. Botany \& Zoology, 27-40.

Lazarido, E. (1994). Systematic, bionomic and ecological study of marine phytobenthos of Milos Island (Cyclades, Greece). PhD Thesis, Univ. Thessaloniki, Greece, 279 p. + 75p. Anex.

Lima-Filho, J. V. M.; Carvalho, A. and Freitas, S. M. (2002). Antimicrobial activity of extracts of six macroalgae from the Northeastern Brazilian Coast. Brazilian Journal of Microbiology, 33: 311-313.

Linda, E. G. and Lee, W. W. (2000). Algae. University of Wisconsin. Prentice Hall. Upper Saddle River, NJ 07458. USA.

Nizamuddin, M. (1985). A new species of Cystoseira C. Ag. (Phaeophyta) from the eastern Part of Libya. Nova Hedwigia. Band 42. Braunschwig. J. Cramer, pp.119-125.

Nizamuddin, M. and El-Menifi, F. (1993). A new species of the genus Codium (Chlorophyta-Codiales) from the eastern coast of Libya. Pak. J. Bot., 25(2): 208-214. 
Nizamuddin, M. and Godeh, M. M. (1989). Stypopordium tubruqense (Phaeophyta, Dictyotales), a new species from the Mediterranean Sea. Willdenowia, 18: 603-608.

Nizamuddin, M. and Godeh, M. M. (1990a). A first record of the genus Cottoniella Børgesen (Ceramiales, Rhodophyta) from Libya. Pak. J. Bot., 25(1):24-35.

Nizamuddin, M. and Godeh, M. M. (1990b). Studies on the new species of Cottoniella from the coast of Libya. Pak. Jour. Bot., 22: 24-35.

Nizamuddin, M. and Godeh, M. M. (1990c). Studies on the genera Chaetomorpha Kütz. and Rhizoclonium Kütz. (CladophoralesCladophoraceae) from the Libyan coast. National Herbarium Uni. AlFateh, Tripoli. Bull. ULT, 2: 11-37.

Nizamuddin, M. and Godeh, M. M. (1993). Observations on Taonia atomaria F. ciliate (Lamour.) Nizamuddin. Pak. J. Bot., 25(2): 199-207.

Nizamuddin, M.; West, J. A. and Menez, E. G. (1979). A list of marine algae from Libya. Bot. Mar., 22: 465-476.

Pampanini, R. (1931). Prodromo della Cirenaica. Algae. Pp. 1-40.

Peres, J. M. and Picard, J. (1964). Nouveau manuel de bionomie benthique de la mer Méditerranée. Rec. Trav. St. Mar. Endoume, 31 (47): 5-137.

Piazzi, L.; Meinez, A.; Verlaque, M.; Ali, A.k.C.; Antolic, B.; Argyrou, M.; Balata, D.; Ballesteros, E.; Calvo, S.; Cinelli, F.; Cirik, S.; Cossu, A.; D'Archino, R.; Djellouli, S. A.; Javel, F.; Lanfranco, E.; Mifsud, C.; Pala, D.; Panayotidis, P.; Peirano, A.; Pergent, G.; Petrocelli, A.; Ruitton, S.; Zuljvic, A. and Ceccherelli, G. (2005). Invasion of Caulerpa racemosa var. cylindracea (Caulerpales, Chlorophyta) in the Mediterranean Sea: an assessment of the spread. Cryptogam. Algol., 26: 189-202.

Pinedo, S.; Garcia, M.; Satta, M. P.; Torras, X. and Ballesteros, E. (2007). Rocky-shore communities as indicators of water quality: a case study in the Northern Mediterranean. Mar. poll. Bull., 55: 126-135.

Said, A. A.; El-Ayouty, Y. M.; Hussien, A. H. and El-Shafei, M. A. (2005). Preliminary studies on epiphytic algae associated with some dominated macrophytes in water habitats, Bull. Faculty of Science, Zagazig University, Egypt, 27: 87-108.

Sorenson, T. (1948). A method of establishing group of equal amolitude in plant sociology based on similarity of species content. Det. Kong. Danske Vidensk. Biol. Skr. (Copenhagen), 5(4): 1-34.

Turk, R.; Orlando-Bonaca, M.; Dobrajc, Z. and Lipej, L. (2007). Cystoseira communities in the Solvenian coast and their importance for fish fauna. Proceeding of the $3^{\text {rd }}$ Mediterranean symposium on marine vegetation. 2729 March 2007 - Marseilles. 203-208. France. 
Tüney, I.; Çadircl., B. H.; Ünal, D. and Sukatar, A. (2006): Antimicrobial Activity of the Extracts of Marine Algae from Coast of Urla (Izmir, Turkey). Turk. J. Biol., 30: 171-175.

Tsiamis, K.; Panayotidis, P. and Montesanto, B. (2007). Contribution to the study of the marine vegetation of Rhodes Island (Greece). Proceeding of the $3^{\text {rd }}$ Mediterranean symposium on marine vegetation. 27-29 March 2007 - Marseilles. 190-196. France.

Tsirika, A. (2005). Study of marine phytobenthos of the Zakinthos national park. Ph D Thesis, Biology Department, Univ. Thessaloniki, Greece.

Wilhm, J. L. (1975). Biological indicators of pollution- In: Whitton, B. A. (ed.), River ecology. - Blackwell. Oxford: pp. 375-400.

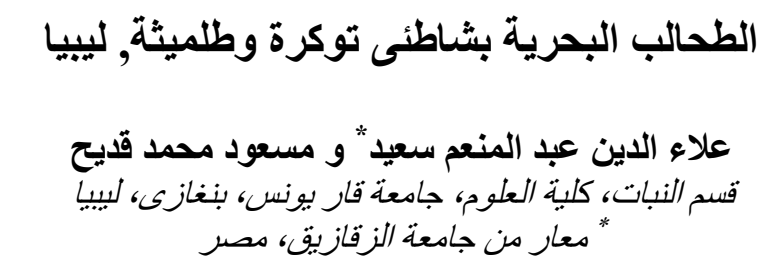

يهتم البحث أساسـا بعمل قاعدة بيانـات حديثة للطحالب البحريـة الليبيـة بالسـاحل الليبي الذيى يمتد

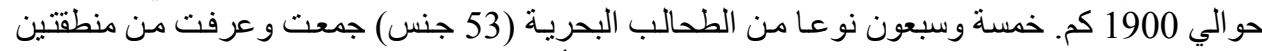

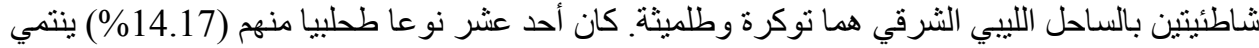

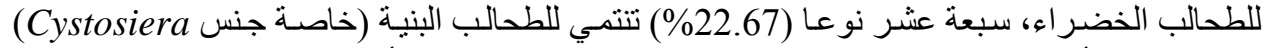

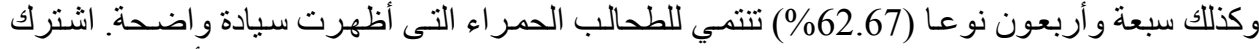

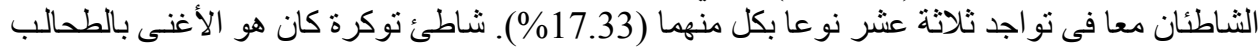

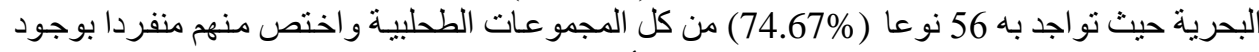

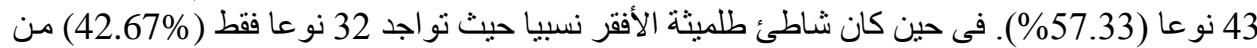

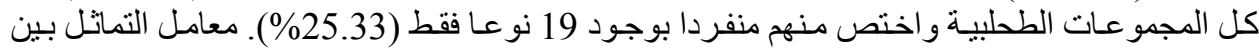

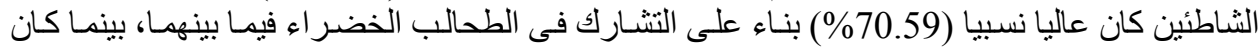

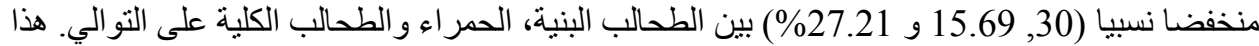
وكان كثير من الطحالب المجمعة من منطقة الدر اسـة مؤشر ات بيئيسة للجودة وذات الهر أهميـة اقتصـادية كبيرة تحتاج للمزيد من الدر اسات المستقبلية. 